\title{
Online Appendix: \\ Immigration and the Diffusion of Technology: The Huguenot Diaspora in Prussia
}

\author{
by Erik Hornung
}

\section{Appendix A Excerpt from the Edict of Potsdam, 1685}

\begin{abstract}
Article 3
German original

Weilen Unsere Lande nicht allein mit allen $\mathrm{zu}$ des Lebens Unterhalt erforderten Nothwendigkeiten wol und reichlich versehen, sondern auch zu établirung allerhand Manufacturen, Handel und Wandels zu Wasser und zu Lande sehr bequem, als stellen Wir denen, die darinn sich werden setzen wollen, allerdings frey, denjenigen Ort, welchen sie in Unserm Herzogthum Cleve, den Graffschafften Marck und Ravensberg, Fürstenthümern Halberstadt und Minden, oder auch in dem Herzogthum Magdeburg, Chur-Marck-Brandenburg und Herzogthümern Pommern und Preussen zu ihrer Profesion und Lebens Art am bequemsten finden werden, zu erwählen; Und gleichwie Wir dafür halten daß in gedachter Unserer ChurMarck-Brandenburg die Städte Stendal, Werben, Rathenow, Brandenburg und Franckfurt und in dem Herzogthum Magdeburg die Städte Magdeburg, Halle und Calbe, wie auch in Preußen die Stadt Königsberg, so wol deßhalb weil daselbst sehr wolfeil $\mathrm{zu}$ leben als auch wegen der allda sich befindenden facilität zur Nahrung und Gewerb vor sie am bequemsten seyn werden Als haben Wir die Anstalt machen lassen befehlen auch hiemit und Krafft dieses so bald einige von erwehnten EvangelischReformierten Französischen Leuten daselbst ankommen werden daß alßdan dieselben wol auffgenommen und $\mathrm{zu}$ allemdem so $\mathrm{zu}$ ihrem établissement nöthig ihnen aller Müglichkeit nach verholffen werden soll.

\section{English translation}

Because our country is convenient with everything one needs for a living and for establishment of manufactories, trade and commerce by water and land we make available for those who want to settle at whichever place they find in Our Duchy of Cleves, the Counties of Mark and Ravensberg, Principalities of Halberstadt and Minden or in the Duchy of Magdeburg, the Margraviate of Brandenburg and the Duchies of Pomerania and Prussia convenient for their profession and lifestyle; Although we recommend the cities Stendal, Werben, Rathenow, Brandenburg and Frankfurt in Our Margraviate of Brandenburg, Magedeburg, Halle and Calbe in the Duchy of Magdeburg, as well as the city of Königsberg in Prussia because they are most comfortable to live in as well as there is enough facility for food and craft and We already ordered and hereby command that as soon as some of the mentioned evangelic-reformed French people arrive, that they shall be accommodated and given everything needed and possible for their establishment (Own translation).
\end{abstract}




\section{Appendix B Productivity Data and Imputation}

The firm-level data used in this work was taken from the "Register of Factories in the Prussian State" conducted by the Royal Prussian Privy Filing Department in 1802 (Krug, 1805, pp. 219-381). The information was collected by inspectors who annually surveyed all manufactories in their area of responsibility and had to send in standardized and printed tables with the requested information on type, location, number of workers, number of looms, value of raw materials used, and value of production in Prussian Thalers. Manufactories are classified by their main input material into 19 categories (wool, linen, cotton, silk, leather, metals, oil-, groat- , and cutting mills, paper mills, tobacco, sugar, glass, soap, powder, earthenware, vinegar, wax, and miscellaneous). The dataset includes 750 textiles manufactories and 1025 non-textiles manufactories. Since we exclude manufactories in rural areas and comparable town-level information is unavailable for areas not belonging to Prussia after $1807,{ }^{1}$ our dataset is reduced to 693 observations in textiles and 694 observations in non-textiles for most specifications.

Historical records often suffer from missing data for reasons unknown and irreparable. The only category used in our empirical analysis which is missing data is the value of raw materials, where missings amount to 15 percent of observations. While the mechanism generating the missing data is unknown, we are able to observe a geographical pattern. Almost every province is missing few (25 ) observations, the exception being the provinces Kurmark and Littauensches Department, where all observations are missing. We assume that the assigned inspectors simply did not collect or report this information. This would imply that the values of the missing observations are not dependent on the value of the variable itself but on the location. Dropping all observations with missing data would reduce the sample size severely and introduce bias if the remaining observations are not representative of the full population of interest. This makes imputational methods the first choice to address the problem (Rubin, 1987; Little and Rubin, 2002).

To attain a complete dataset, we impute missing data in the explanatory variable (ln) materials with all other variables used for the extensive regression in column 4 of Table 2, (ln) output, (ln) workers, (ln) looms, the share of Huguenots in 1700 , (ln) town population 1802 , merino sheep per capita 1816 , the share of Protestants and a dummy for towns not belonging to Prussia before 1720 . We fill the missing data using linear regression methods for continuous variables (the Gaussian normal regression). We employ the univariate multiple imputation method, developed and implemented by Royston (2009) and StataCorp (2009, pp. 181-185).

Since the process that generated the missing values is unknown, the probability to have a missing value might depend on unobserved characteristics not included in the imputation. These unobservables again might influence output of the manufactory systematically. In such a case we would predict identical val-

\footnotetext{
${ }^{1}$ These are East Frisia, New East Prussia, New Silesia, and parts of South Prussia which only belonged to Prussia for a very short period. They form the spotted areas in Figure 2 .
} 
ues for manufactories with identical observed but possibly different unobserved characteristics and bias the estimates in an unknown direction.

To make sure our estimates are not driven by imputed data, we include an imputation dummy in all of our regressions. The dummy becomes 1 if data on the value of raw materials used were originally missing for the observation.

\section{Appendix C Population Loss Data and Construc- tion of the Instrument}

We compiled a database on population losses during the Thirty Years' War for those towns with textile manufactories in 1802. The data were assembled from three different sources, each providing a consistent overview over a certain area.

The most extensive source is the Deutsches Städtebuch (Handbook of German Towns) by Keyser (1939-1974). This compendium provides a vast amount of information for all German towns including population data for various points in time. To calculate the population losses during the war period, we would ideally need population data for the years 1625 (Brandenburg did not enter the war until 1626) and 1652, which are the breaks also used in other sources (Wohlfeil, 1976). Unfortunately, information about town population for the period in question is very rare and data for these exact years is even more scarce.

When available, we used data as close as possible to said years and interpolated them to match the beginning and the end of the war. The earliest date used is 1550 and the latest date is 1685 . The interpolation was undertaken using population growth rates for Germany calculated in Pfister (2007).

Table C-1: Population Growth in Germany (1914).

\begin{tabular}{c|c}
\hline Period & Growth Rate \\
\hline $1541-1550$ & 7.2 \\
$1551-1560$ & 7.1 \\
$1561-1570$ & 5.8 \\
$1571-1580$ & 4.6 \\
$1581-1590$ & 4.1 \\
$1691-1600$ & 3.2 \\
$1601-1625$ & 3.2 \\
$1626-1650$ & -13.4 \\
$1651-1700$ & $8-10$ \\
\hline \multicolumn{2}{c}{ Annual growth rates in per mill calculated after Pfister $(2007$, p. 10$)$}
\end{tabular}

For example, if a town had a population of 1000 in the year 1600, we use the growth rates to estimate a population of 1080 in 1625 . If the population had reached 700 in 1660, we estimate a population of 650 in 1652. The population loss would thus be 40 percent, instead of 30 percent if we do not interpolate. 
We only included towns if information on the number of residents, households, fireplaces or citizen was available both before and after the war. Finally, we used only those pieces of information where the unit of observation was the same for both dates. Cases which, for example, reported the number of houses in a town before the war and the number of fireplaces after the war, were excluded. Comparability between towns with different units of observation is granted since we calculated growth rates. A total of 57 towns matched the criteria for inclusion. Interpolation increases the power of the instrument (F-test increases from 3.7 to 4.8 in Table 4$)$.

To smooth out overstatements, we calculate average population losses from different sources and use it as an instrument in Table 5. Due this procedure, we gathered information for a total of 71 different towns for which we also had data on textile manufactories and Huguenot immigration. The sources are chosen because, to our knowledge, they are the only ones providing comparable information for a larger number of towns.

The second source is a map produced by Wohlfeil (1976), showing the percentage of population losses in towns during the Thirty Years' War in the Margraviate of Brandenburg between 1625 and 1652/53. Similar to our procedure, Wohlfeil (1976) calculates the population losses from information on the number of active fireplaces and houses from four different sources. ${ }^{2}$ A total of 48 towns matched the criteria for inclusion into our dataset.

The third source is a population table for towns in the Kurmark and the Neumark, published in Behre (1905, pp. 58-59). He uses official sources, including archival files from the Prussian Privy State Archive that report the number of fireplaces or citizen. Based on that, an approximate population range for the years 1625 and 1645 is reported. We extract the arithmetic mean of this range and calculate the population loss over this period. A total of 37 towns matched the criteria for inclusion into our dataset.

\section{References}

Behre, Otto. 1905. Geschichte der Statistik in Brandenburg-Preussen bis zur Gründung des Königlich Statistischen Bureaus. Berlin: Carl Heymanns Verlag.

Keyser, Erich. 1939-1974. Deutsches Städtebuch-Handbuch städtischer Geschichte. Vol. 1-5, Stuttgart: Kohlhammer.

Krug, Leopold. 1805. Betrachtungen über den Nationalreichtum des preußischen Staates und über den Wohlstand seiner Bewohner. Vol. 2, Berlin: J. F. Unger.

Little, Roderick J. A., and Donald B. Rubin. 2002. Statistical Analysis with Missing Data, 2nd ed. New York, NY: Wiley.

\footnotetext{
${ }^{2}$ See addendum to the map for further information on his calculations (Wohlfeil, 1976, pp. 3-4).
} 
Pfister, Christian. 2007. Bevölkerungsgeschichte und historische Demographie 1500-1800. München: Oldenbourg.

Royston, Patrick. 2009. "Multiple Imputation of Missing Values: Further Update of Ice, With an Emphasis on Categorical Variables." Stata Journal, 9(3): 466-477.

Rubin, Donald B. 1987. Multiple Imputation for Nonresponse in Surveys. New York, NY: Wiley.

StataCorp. 2009. "Stata Multiple-Imputation Reference Manual - Release 11." College Station, Texas.

Wohlfeil, Rainer. 1976. "Kriegsverlauf 1635 bis 1642 - Bevölkerungsverluste der brandenburgischen Städte zwischen 1625 und 1652/53. (Der Dreißigjährige Krieg II).” Berlin: de Gruyter. 